\title{
Pengembangan Materi Ajar Bahasa Indonesia Berbasis Lingkungan
}

\author{
Oleh: \\ Yulia Nelfita \\ Universitas Negeri Padang \\ Email:yulianelfita16@gmail.com
}

Di seluruh dunia, setiap orang menghadapi masalah lingkungan yang serius, seperti pemanasan global, hujan asam, ozon perusakan lapisan, pencemaran lingkungan, kerusakan alam, dan hilangnya keanekaragaman hayati yang dapat berdampak serius mengancam kehidupan generasi sekarang, terutama generasi yang akan datang Masalah lingkungan disebabkan oleh aktivitas manusia yang ceroboh dan intensif di kawasan alami untuk meningkatkan kualitas hidupnya Aspek yang lebih mengancam adalah ketidaksadaran akan pengaruh manusia di lingkungannya Kerusakan lingkungan mengakibatkan krisis ekologi yang akan menimbulkan serangkaian masalah dengan alam sumber daya, iklim, polusi, makanan, dan ekonomi [5] .

Tugas dari umat manusialah untuk menjaga dan melestarikan lingkungan. Akan tetapi, kenyataannya saat ini alam tidak bersahabat dengan manusia. Keadaan ini terjadi karena adanya keserakahan dari beberapa manusia, yang lebih mengedepankan keegoisan dibanding keselamatan alam dan manusia itu sendiri. Keserakahan dan keegoisan manusia menjadikan alam sekitar tercemar. Keegoisan manusia yang mendoktrin bahwa dirinya yang memiliki bumi ini menjadikan alam mengalami ketidakstabilan. Oleh banyaknya kegiatan eksploitasi alam

Lingkungan menentukan dinamika kehidupan, kesehatan masyarakat, perkembangan spiritual dan moral. Manusia yang hidup saat ini dihadapkan pada permasalahan lingkungan. Kemanusiaan telah lama diakui bahwa keberadaannya tergantung pada status lingkungannya. Setiap orang memiliki tanggung jawab yang sama untuk mengatasi masalah tersebut. Karena kerusakan lingkungan tidak disebabkan dari tempat tertentu, tetapi dapat berasal dari lingkungan sekitar. Kerusakan tidak hanya mempengaruhi kehidupan masa depan, tetapi juga 
saat ini [7]. Di seluruh dunia banyak metode telah diterapkan untuk memecahkan masalah lingkungan, seperti: kebijakan pemerintah, himbauan kepada masyarakat, gerakan pecinta alam, dan penguatan pemerintah

Di Indonesia, pelatihan alam tentu bukan mata pelajaran wajib di sekolah. Selanjutnya, pelatihan lingkungan dapat dimasukkan dalam mata pelajaran yang berbeda, salah satunya adalah belajar bahasa memanfaatkan mata pelajaran lingkungan dalam pembelajaran teks dapat memicu pendapatan siswa dalam mempelajari bahasa dan dengan saran dapat membangun informasi siswatentang lingkungan. Belajar pada dasarnya adalah komunikasi antara individu dan iklim untuk memperoleh sesuatu yang baru sama sekali dari keterlibatannya sendiri dengan komunikasi dengan lingkungan. Ini menunjukkan bahwa lingkungan sangat penting. Pada pengadaan pemahaman siswa tentang latihan yang mereka pertimbangkan.

Pembelajaran bahasa Indonesia memudahkan siswa untuk mengkomunikasikan pikiran. Sehingga kemampuan composing akan jauh lebih unggul. Mengajar bahasa harus dirancang oleh guru mata pelajaran yang disesuaikan dengan pengajaran bahasa nasional, daerah, yang di sesaikan dengan lingkungan masing-masing [2]. Kurikulum memegang peranan penting sesuai dengan konteks pendidikan. Sehingga kegiatan multidimensi dapat terwujud. Kemudian, pada saat itu materi lingkungan sangat penting dalam pembelajaran bahasa Indonesia dan Efektivitas pelatihan juga terkait dengan sumber daya manusia dalam mencapai pelatihan yang diharapkan tujuan, dan kompetensi nara sumber dalam melaksanakan pelatihan. Jackson di Charismi dkk disebutkan, ada empat hal yang dapat mempengaruhi efektivitas latihan. Pertama, kesiapan pelatihan peserta. Kedua, gaya belajar harus disesuaikan kepada pembelajar. Ketiga, penerapan materi yang dipelajari selama pelatihan oleh peserta dalam pekerjaan mereka dan berlangsung lama. Keempat, penyampaian pelatihan materi yang disesuaikan dengan kebutuhan peserta pelatihan [1] Lingkungan yang mendukung sangat diperlukan dalam prosespembelajaran karena alat atau modul pembelajaran mandiri di era kemajuan teknologi sangat dibutuhkan dalam 
proses pembelajaran. Penggunaan teknologi informasi merupakan bagian integral dari pendidikan modern. Informasi teknologi sebagai sarana untuk mengembangkan model pembelajaran dan mempersingkat waktu belajar [6]. Kemajuan teknologi membuat manusia sengaja atau tidak sengaja memilikidan akan berinteraksi dengan teknologi. Guru harus memiliki kompetensi dalam memilih dan menggunakan media dalam pembelajaran yang disesuaikan dengan kebutuhan siswa. Selain itu, guru juga membutuhkan literasi teknologi, memanfaatkan informasi dan teknologi komunikasi untuk berbagi informasi, menjadi model untuk penggunaan teknologi yang efisien dengan sumber daya lingkungan [4]

Media elektronik sebagai akibat dari perkembangan teknologi diterima dan mendapat tempat dan perhatian yang cukup besar bagi siswa dan berpengaruh besar terhadap perkembangan pendidikan.Untuk mengefektifkan prestasi belajar kognitif siswa, fasilitas modul pembelajaran yang menarik adalah dibutuhkan dalam proses pembelajaran dan dapat meningkatkan kualitas pembelajaran. Kebutuhan untuk mengajar yang disesuaikan dengan lingkunga [3]. Di Indonesia sendiri perkembangan ilmu pengetahuan dan teknologi, menciptakan masyarakat yang terus berupaya untuk meningkatkan kemampuannya di dalam dunia pendidikan. Pendidikan merupakan wujud dari suatu kemajuan. Suatu masyarakat yang maju adalah ditandai dengan majunya sektor pendidikan yang berkualitas. Pendidikan yang berkualitas tersebut ditandai salah satunya dengan masyarakat yang literat [5].

Masyarakat literat tentu memerlukan apa itu pengenalan lingkungan sangat berpengaruh terhadap pembelajaran bahasa Indonesia, persentasenya menunjukkan $70 \%$ setuju dan $30 \%$ sangat setuju. Pernyataan kedua, pembelajaran bahasa Indonesia memiliki peranan penting untuk mengembangkan pengetahuan tentang lingkungan, kesadaran lingkungan, dan perubahan perilaku Pernyataan ketiga, lingkungan dijadikan sebagai sumber inspirasi untuk membangun kecerdasan kebahasaan, Pernyataan keempat, pembelajaran berbasis lingkungan bertujuan untuk membuat siswa berpartisipasi dalam menjaga dan melindungi sekitar, Kemudian pernyataan kelima, dalam pembelajaran bahasa Indonesia guru 
harus menggunakan teks-teks yang bertemakan lingkunganPernyataan keenam, salah satu cara untuk menciptakan suasana belajar yang kondusif dapat dilakukan dengan memanfaatkan lingkungan sekitar guna mengembangkan aktivitas dan kreatifitas belajar secara optimal. Pernyataan ketujuh, kemampuan berbicara dan memahami bahasa dipengaruhi oleh faktor lingkungan,. Pernyataan kedelapan, guru memiliki peranan penting dalam mengenalkan pendidikan lingkungan melalui pembelajaran di kelas, persentasenya Pernyataan kesembilan, dalam kaitannya antara pembelajaran bahasa Indonesia dengan lingkungan, siswa bisa mengamati apa saja yang ada di lingkungan sekitar. Kemudian menjadikan pengamatan tersebut sebagai salah satu sumber inspirasi untuk membuat salah satu karya sastra berupa teks laporan hasil observasi, Pernyataan kesepuluh, pemanfaatan lingkungan belajar diharapkan mampu membantu proses perkembangan individu menjadi makhluk sosial yang dapat beradaptasi degan baik di lingkungannya, persentase dari pernyataan ini. Bentuk tulisan ini dipakai sebagai bahan evaluasi bersama bagi penulis, pembaca dan khalayak luas untuk tetap menjaga lingkungan.

\section{Referensi}

[1] Agusrida, Atmazaki, Syahrul. "Effectiveness of Online Scientific Publication Training Approach for Teacher's Professional Competence Development at Religious Training Centre in Padang” IcolE 2020., vol 504

[2] Indiriyani Vivi, Syahrul Ramadhan, Atmazaki." Literasi Baca Tulis dan Inovasi Kurikulum Bahasa". Kembara. Volume 5. No 1. 2019.

[3] Mulyadi, Syahrul r, Atmazaki. "The Development of E-Modules Based on Adobe Flash for Indonesian Subject at IAIN Bukittinggi”. IOP Conf. Ser. Journal of Physics: conf. series 1471.2020.

[4] Mulyadi, Syahrul.R. "The Development of Interactive Multimedia EModule on Indonesia Language Course”. IcolE 2018. Vol 178.

[5] S. Ramadhan, E. Sukma, and V. Indriyani. "Environmental education and disaster mitigation through language learning," IOP Conf. Ser. Earth Environ. Sci., vol. 314, p. 012054, 2019.

[6] S. Ramadhan, E. Sukma dan V. Indriyani. "Teacher Competence in Utilizing Media Literacy in Education" Journal of Phisics: Conference Series 1339 (2019).

[7] Ramadhan.S, Yasnur Asri. "Learning Module Design Writing Argumentative Text Based Problem-Based Learning”ICLLE 2018. Vol 263 
